\title{
Studies on Escherichia coli B in the Lag Phase of Growth
}

\author{
N. A. ELIASSON, E. HAMMARSTEN, H. PALMSTIER N \\ and S. $\AA Q$ V I S T \\ Karolinska Institutet, Departments of Chemistry and Bacteriology, Stockholm, Sweden \\ and \\ L. R E I O \\ Wenner-Gren Institute, Department of Physiological Chemistry, Stockholm, Sweden
}

\begin{abstract}
The growth of $E$. coli B in the lag-phase of growth was investigated by analysis of the amounts of proteins, RNA, DNA and glycogen. The cells had been labeled with ${ }^{13} \mathrm{C}$ in a preculture running into the stationery phase, and were then cultivated in a medium labeled with ${ }^{14} \mathrm{C}$ and ${ }^{15} \mathrm{~N}$.

The relative increase in amount per litre culture followed the sequence: Glycogen $>$ RNA $>$ DNA $>$ protein.

The role of cell precursors relative to that of the medium is discussed.
\end{abstract}

Drevious work ${ }^{1,2}$ led us to investigate some processes during the lag phase 1 that starts when $E$. coli B cells, harvested from a culture in the stationary phase, are incubated in a fresh medium and prepare themselves for fission. Preliminary experiments with cells labeled with ${ }^{15} \mathrm{~N}$ had shown that a redistribution of the nitrogen in the cells occurred simultaneously with an incorporation of nitrogen from the medium. This implies a very complex metabolic pattern in the lag-phase which may correspond to similar stages of growth in other cells. In spite of this anticipated complexity we have tried the method of prelabeling the cells and then cultivating them in a fresh medium labeled in another way. The cells were prelabeled with ${ }^{13} \mathrm{C}$. The new medium contained lactate $\left({ }^{14} \mathrm{CH}_{3} \mathrm{CH}(\mathrm{OH}) \mathrm{COO}^{-}\right)$as the only carbon source and ${ }^{15} \mathrm{~N}$-labeled ammonium chloride as the only nitrogen source. Samples were taken at zero time and after $5,25,50$ and $80 \mathrm{~min}$ of cultivation.

The rates of relative increase in amounts were found to be: Glycogen $>$ RNA $>$ DNA $>$ Proteins (Fig. 1.). This is in accordance with earlier findings ${ }^{\mathbf{1}, 2}$. No carbon, once incorporated, disappeared from the cells. The proteins incorporated carbon from cell sources during the first $50 \mathrm{~min}$. The same was the case

Acta Chem. Scand. 11 (1957) No. 8 
with glycogen during the first $50 \mathrm{~min}$. The proteins incorporated practically all their nitrogen from the medium but RNA and DNA used rather much nitrogen, that was present in the cells at the moment of inoculation.

\section{EXPERIMENTAL}

$E$. coli B was grown in Friedleins salt-sodium lactate medium. The lactate was labeled with ${ }^{18} \mathrm{C}$ in the methyl group. The atom per cent excess ${ }^{13} \mathrm{C}$ in the medium was 5.45 at zero time and 2.35 after $18 \mathrm{~h}$ cultivations. The cells were harvested and washed in tracerfree medium and then inoculated into fresh medium with ${ }^{14} \mathrm{C}$ label in carbon 3 of the lactate and ${ }^{15} \mathrm{~N}$ label in the ammonium chloride. The cultivation was carried our in four 30 litres pyrex flasks in a waterbath at $37^{\circ} \mathrm{C}$. The culture volume was 20 litres. The cultures were aerated at a rate of 1 litre per min and litre of medium. The flasks were arranged around a vertical axis and were driven back and forth by a compressed-air motor. The flasks were emptied at appropriate times and the cultures cooled with a cooling coil. The taking of a sample and its cooling to $+3^{\circ}$ to $+4^{\circ} \mathrm{C}$ took $3,5-4$ min. A small sample was taken for counting the number of cells under the phase contrast microscope in a Bürker chamber and the rest of the culture was centrifuged at $0^{\circ} \mathrm{C}$ at $2500 \times g$ for $2 \mathrm{~h}$ in stainless steel tubes fitted with baffles and a netting of stainless steel at the bottoms of the tubes to prevent the cells from whirling up during the retardation of the centrifuge. The number of cells remaining in the supernatant was determined by counting the number of colonies produced on endo agar plates. Less than $1.5 \times 10^{4}$ cells $/ \mathrm{ml}$ were left in the supernatant. Tests on blood and endo agar plates did not show any contamination with foreign cells. The sediment was washed 3 times at $0^{\circ} \mathrm{C}$ with tracer-free medium in a centrifuge at $25000 \times g$. The harvesting of the cells and the centrifuging were carried out on a quantitative basis in order to ensure the calculation of the number of cells per unit final dry weight.

Previously we had tried to calculate the number of cells in a freeze-dried sample by resuspending part of the sample and counting the cells. No accurate estimate could be made in this way, since part of the cells disappeared, possibly due to a fragility induced by the freeze-drying process. For this reason the cell concentration in the culture was estimated and the cells harvested and lyophilized in a quantitative way. The dry weight was estimated by weighing a small part of the lyophilized material and drying it to constant weight $\left(90^{\circ} \mathrm{C}, \mathrm{P}_{2} \mathrm{O}_{5}\right.$ vacuum). The figures listed in Table 1 are calculated on dry weight and this weight is corrected for the amount of medium solids enclosed in the sample (about $5 \%$ of the dry weight). It was assumed that the loss in weight during the drying procedure corresponded to water from a solution with the same content of solute as the medium. This approximation may be justified, especially as the corrections were too small to affect the main conclusions.

The extractions of DNA and RNA were carried out on 400 to $500 \mathrm{mg}$ dry cells. The cells were mixed with $10 \mathrm{ml}$ of pyrex beads $(0.28 \mathrm{~mm}$ diam.) and $30 \mathrm{ml}$ of $30 \%(\mathrm{v} / \mathrm{v})$ cold ethanol and disintegrated by shaking them at high rates in a Griffith shaker at $-15^{\circ} \mathrm{C}$. The contents remained in the same tube through all manipulations. After freezedrying and extraction with boiling ethanol-ethylether $(3: 1)$ the lipidfree cells were extracted for DNA and RNA according to Hammarsten ${ }^{3}$. The hot TCA-extractable phosphorus in the undissolved residue was determined after combustion. The following values were obtained and are expressed as per cent of the total phosphorus in the extracted polynucleotides:

\begin{tabular}{|l|c|c|c|c|c|}
\hline Cultivation times in min & 0 & 5 & 25 & 50 & 80 \\
\hline $\begin{array}{l}\text { Phosphorus in per cent of } \\
\text { phosphorus in polynucleotides }\end{array}$ & 7.1 & 9.0 & 8.3 & 6.6 & 7.6 \\
\hline
\end{tabular}

Over $90 \%$ of the polynucleotides were thus extracted. 
Fig. 1. (From Table 2.)

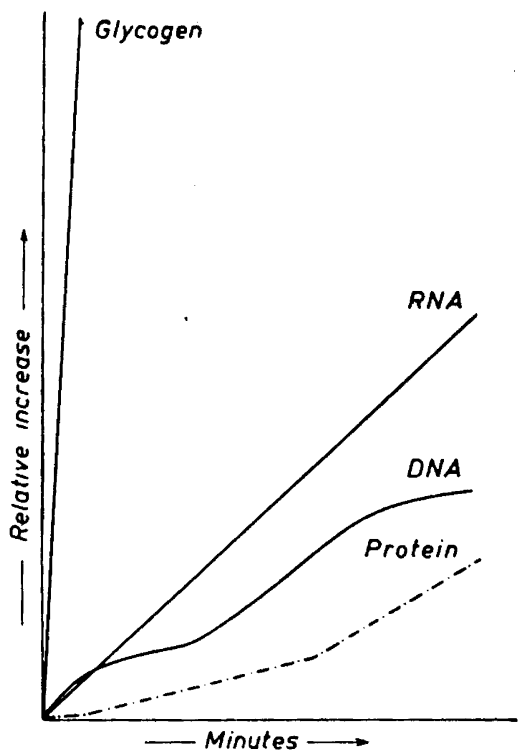

After hydrolysis with alkali the mononucleotides of RNA were separated 4 on Dowex 2 (elution with formic acid). Cytidylic and adenylic acids were further purified on Dowex 2 (elution with $0.01 \mathrm{~N} \mathrm{HCl}$ ). These two fractions and uridylic and guanylic acids from the formic acid elution were separated together on Dowex 50 in the $\mathrm{H}+$ form, previously washed with water until the eluate was neutral. Uridylic acid was eluted with water, cytidylic acid with $0.01 \mathrm{~N} \mathrm{HCl}$, guanylic and adenylic acids (well separated from each other) with $0.02 \mathrm{~N} \mathrm{HCl}$.

Uridylic and cytidylic acids were analysed for tracer content without any further purification. Parts of the guanylic and adenylic acids were analysed in the same way and the rest hydrolysed $\left(1 \mathrm{~h}, 100^{\circ} \mathrm{C}, \mathrm{N} \mathrm{HCl}\right)$. The products of each nucleotide were separated on Dowex 50 as above. By elution with water the first few tubes showed a very weak light absorption at $260 \mathrm{~m} \mu$. This fraction was considered as ribose. Guanine and adenine

Table 1.

\begin{tabular}{|c|c|c|c|c|c|c|c|c|}
\hline \multirow[b]{2}{*}{ 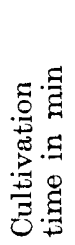 } & \multirow{2}{*}{ 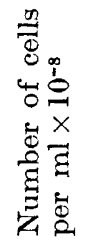 } & \multirow{2}{*}{ 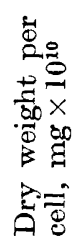 } & \multicolumn{6}{|c|}{$\mathrm{Mg} \times 10^{12}$ per cell of: } \\
\hline & & & 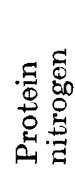 & $\begin{array}{l}\tilde{D} \\
80 \\
8 \\
0 \\
D \\
0\end{array}$ & 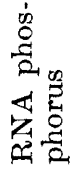 & 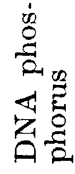 & 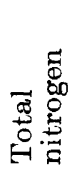 & 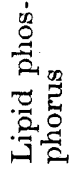 \\
\hline 0 & 2.3 & 1.8 & I8. & 2.2 & 1.23 & 0.43 & 26.0 & 0.43 \\
\hline 5 & 2.2 & 2.1 & 19.9 & 12.2 & 1.53 & 0.57 & 27.9 & 0.43 \\
\hline 25 & 2.2 & 2.6 & 23.8 & 29.1 & 2.47 & 0.68 & 33.9 & 0.37 \\
\hline 50 & 2.1 & 3.2 & 29.0 & 41.6 & 3.72 & 1.05 & 43.2 & 0.53 \\
\hline 80 & 2.9 & 3.5 & 32.1 & 32.8 & 3.93 & 0.93 & 47.8 & 0.38 \\
\hline
\end{tabular}

Acta Chem. Scand. 11 (1957) No. 8 
Table 2. Relative increase of cellular constituents during the lag phase.

\begin{tabular}{|c|c|c|c|c|c|c|c|}
\hline 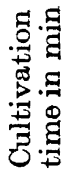 & 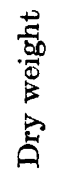 & 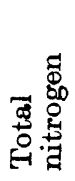 & $\begin{array}{l}\mathbb{0} \\
\stackrel{0}{0} \\
8 \\
\stackrel{0}{\sigma}\end{array}$ & 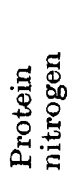 & 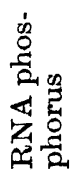 & 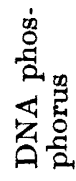 & 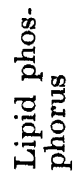 \\
\hline 0 & 1.00 & 1.00 & 1.00 & 1.00 & 1.00 & 1.00 & 1.00 \\
\hline $\mathbf{5}$ & 1.11 & 1.0 & 5.55 & 1.01 & 1.19 & 1.26 & 0.96 \\
\hline 25 & 1.40 & 1.26 & 12.9 & 1.22 & 1.94 & 1.52 & 0.83 \\
\hline 50 & 1.67 & 1.56 & 17.9 & 1.45 & 2.84 & 2.29 & 1.15 \\
\hline 80 & 2.44 & 2.33 & 19.1 & 2.16 & 4.05 & 2.72 & 1.13 \\
\hline
\end{tabular}

were then eluted with $2 \mathrm{~N} \mathrm{HCl}$. The bases were mixed and run on a Dowex 50 column $(6 \times 0.6 \mathrm{~cm})$ and eluted again with $2 \mathrm{~N} \mathrm{HCl}$. They were obtained in very small volumes. The different fractions were evaporated and dissolved in water. The amounts of nucleotide carbon were calculated from the determinations of phosphorus. The amounts of purine carbon were calculated from determinations of nitrogen. In both cases (nucleotides and purines) samples were combusted (dry) and total carbon determined as barium carbonate. The amounts of "ribose" were calculated from combustion. The measurements of the radioactivity were performed in a windowless gas flow counter with less than $20 \mu \mathrm{g}$ of material per $\mathrm{cm}^{2}$. The corrections for foreign carbon (total carbon by combustion divided by the carbon calculated from determinations of $P$ and $N$ ) ranged from 1.2-3.0 but was in most cases 1.2-2.0. No correction could be made in the case of ribose.

The degradation of DNA was carried out according to Hurst et al.s. The chromatographic separations were in all essentials the same as for the nucleotides from RNA. The correction terms for foreign carbon were within the same limits as those for the RNAproducts.

The protein fractions were determined in separately weighed samples of lyophilized cells. These were disintegrated in the way described above, lyophilized and treated accord-

Table 3.

\begin{tabular}{|c|c|c|c|c|c|c|c|c|c|c|c|c|}
\hline \multicolumn{5}{|c|}{ Atom per cent excess of ${ }^{15} \mathrm{~N}$} & \multicolumn{3}{|c|}{$\begin{array}{l}\text { Specific activity of } \\
{ }^{14} \mathrm{C} \text { : c.p.m. per } \mu \mathrm{g} \mathrm{C}\end{array}$} & \multicolumn{4}{|c|}{ Atom per cent excess ${ }^{13} \mathrm{C}$} & \multirow[b]{2}{*}{ 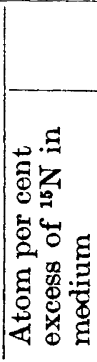 } \\
\hline 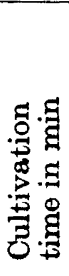 & 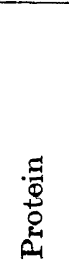 & $\underset{Z_{1}}{\mathbb{Z}_{1}}$ & 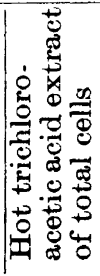 & 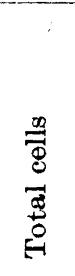 & 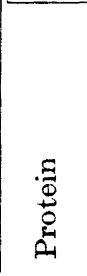 & 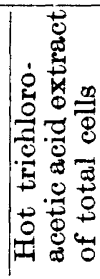 & 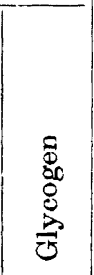 & 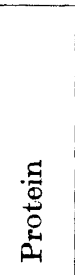 & $\begin{array}{l}\mathbb{D} \\
0 \\
8 \\
\stackrel{0}{0} \\
\frac{2}{\sigma}\end{array}$ & 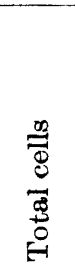 & 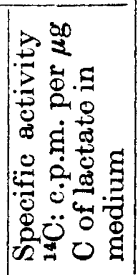 & \\
\hline 0 & & & - & & & - & & & & & 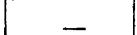 & \\
\hline 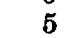 & & & 0.3 & & & & & & & & & \\
\hline 25 & & & & & & 6. & & & & & & \\
\hline & & & 2. & & & 6.32 & & & & & 3 & \\
\hline & & 2.75 & 2.6 & & 9.46 & - & $|10.28|$ & & & & 30 & \\
\hline
\end{tabular}

Acta Chem. Scand. 11 (1957) No. 8 
Table 4. Isotopic data on the components in the protein and nucleic acid fractions. Atom per cent excess ${ }^{15} \mathrm{~N}$.

\begin{tabular}{|c|c|c|c|c|c|}
\hline \multicolumn{2}{|c|}{ Cultivation time in minutes } & 5 & 25 & 50 & 80 \\
\hline 至 & $\begin{array}{l}\text { Uridylic acid } \\
\text { Cytidylic acid } \\
\text { Adenine } \\
\text { Guanine } \\
\end{array}$ & $\begin{array}{l}0.12 \\
0.25 \\
0.34 \\
0.37 \\
\end{array}$ & $\begin{array}{l}0.66 \\
0.90 \\
1.32 \\
1.41\end{array}$ & $\begin{array}{l}1.77 \\
1.94 \\
2.15 \\
2.44 \\
\end{array}$ & $\begin{array}{l}2.51 \\
2.69 \\
2.74 \\
2.76\end{array}$ \\
\hline 厽 & $\begin{array}{l}\text { Thymidylic acid } \\
\text { Cytidylic acid } \\
\text { Adenine } \\
\text { Guanine }\end{array}$ & $\begin{array}{l}0.06 \\
0.11 \\
0.06 \\
0.12 \\
\end{array}$ & $\begin{array}{l}0.30 \\
0.49 \\
0.62 \\
0.64 \\
\end{array}$ & $\begin{array}{l}0.72 \\
1.22 \\
1.27 \\
1.32\end{array}$ & $\begin{array}{l}1.58 \\
1.78 \\
1.59 \\
1.89\end{array}$ \\
\hline 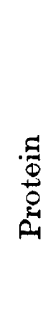 & $\begin{array}{l}\text { Glutamic acid } \\
\text { Glycine } \\
\text { Methionine } \\
\text { Serine } \\
\text { Leucine+isoleucine } \\
\text { Valine } \\
\text { Alanine } \\
\text { Threonine } \\
\text { Aspartic acid } \\
\text { Proline } \\
\text { Tyrosine }\end{array}$ & $\begin{array}{l}0.14 \\
0.09 \\
0.08 \\
0.10 \\
0.12 \\
0.11 \\
0.07 \\
0.08 \\
0.12 \\
0.04 \\
0.13\end{array}$ & $\begin{array}{l}0.71 \\
0.60 \\
0.56 \\
0.62 \\
0.67 \\
0.64 \\
0.36 \\
0.61 \\
0.64 \\
0.42 \\
0.60\end{array}$ & $\begin{array}{l}1.48 \\
1.38 \\
1.25 \\
1.36 \\
1.43 \\
1.41 \\
1.10 \\
1.37 \\
1.37 \\
1.16 \\
1.31\end{array}$ & $\begin{array}{l}2.28 \\
2.22 \\
1.81 \\
2.17 \\
2.24 \\
2.21 \\
2.02 \\
2.20 \\
2.18 \\
1.91 \\
2.14\end{array}$ \\
\hline
\end{tabular}

ing to Schneider. The protein precipitate was hydrolysed for $18 \mathrm{~h}$ in $6 \mathrm{~N} \mathrm{HCl}$. The hydrolysate was carefully washed out from the glass beads, evaporated and dissolved to a suitable volume. Protein carbon was directly determined by combustion. No correction was made for foreign carbon. The part that was not used for analyses (Tables 1 and 3) was separated on Dowex 50 and starch $^{6}$ and 11 of the amino acids were isolated (the two leucines as one fraction). The individual amino acids were run again on very small columns. Total carbon was determined as for the RNA derivatives and amino carbon was calculated from determinations of nitrogen. The quotients for correction varied between 1.1 and 2.0. Most of the amino acids, however, did not contain over $30 \%$ foreign carbon.

The lactates labeled with ${ }^{13} \mathrm{C}$ and ${ }^{14} \mathrm{C}$ in $\beta$-position were synthesized according to Reio ${ }^{7}$. Isotopic barium carbonate $\left({ }^{13} \mathrm{C}\right.$ and ${ }^{14} \mathrm{C}$ labeled) was reduced in two different batches with lithium aluminium hydride into methanol, which in turn was converted to methyl iodide and condensed with acetamino-malonic ester. After hydrolysis alanine was isolated and treated with sodium nitrite yielding sodium DL-lactate. The synthesis of ${ }^{14} \mathrm{C}$-labeled compounds from barium carbonate to alanine was carried out in a closed apparatus-system, whereby all reaction steps were performed in a short time with a minimum loss of activity. The lactic acids were purified from remaining alanine and selts by passing them through Dowex 50 columns. The determinations of specific activity in the medium at different times were based on direct determinations of lactic acid ${ }^{8}$ and countings of $8-4 \mu \mathrm{g}$ lactic acid before and after a second separation on Dowex 2 and stepwise elution with water to $0.4 \mathrm{~N} \mathrm{HCl}$.

\section{DISCUSSION AND RESULTS}

The values for the atom per cent excess ${ }^{13} \mathrm{C}$ depend on the rather high corrections for foreign carbon. The determination of carbon as barium carbonate after dry combustion is admittedly not a very exact method. This has certainly

Acta Chem. Scand. 11 (1957) No. 8 
Table 4a. Isotopic data on the components in the protein and nucleic acid and glycogen fractions.

\begin{tabular}{|c|c|c|c|c|c|c|c|c|c|c|}
\hline \multirow{2}{*}{\multicolumn{2}{|c|}{ Cultivation time in minutes }} & \multicolumn{4}{|c|}{$\begin{array}{c}\text { Spec.activity }{ }^{14} \mathrm{C}: \\
\text { per } \mu \mathrm{g}\end{array}$} & \multicolumn{5}{|c|}{ Atom per cent excess ${ }^{18} \mathrm{C}$} \\
\hline & & 5 & 25 & 50 & 80 & $\mathbf{0}$ & 5 & 25 & 50 & 80 \\
\hline$\underset{⿱ 乛 龰}{\mathbb{Z}}$ & $\begin{array}{l}\text { Uridylic acid } \\
\text { Cytidylic acid } \\
\text { Adenylic acid } \\
\text { Guanylic acid } \\
\text { Adenine } \\
\text { Guanine } \\
\end{array}$ & $\begin{array}{l}3.03 \\
1.80 \\
2.67 \\
2.08 \\
2.08 \\
1.51 \\
\end{array}$ & $\begin{array}{l}9.25 \\
4.52 \\
6.04 \\
9.39 \\
8.53 \\
5.73 \\
\end{array}$ & $\begin{array}{l}6.74 \\
6.50 \\
8.17 \\
8.10 \\
8.54 \\
7.78 \\
\end{array}$ & $\begin{array}{l}5.96 \\
5.87 \\
7.83 \\
7.00 \\
7.65 \\
6.16 \\
\end{array}$ & & $\begin{array}{l}3.32 \\
2.10 \\
1.63 \\
1.16 \\
1.96 \\
1.75 \\
\end{array}$ & $\begin{array}{l}1.59 \\
1.49 \\
-\overline{-} 9 \\
1.38 \\
0.58 \\
\end{array}$ & $\begin{array}{l}0.97 \\
1.13 \\
1.42 \\
0.98 \\
0.90 \\
0.36 \\
\end{array}$ & $\begin{array}{l}0.74 \\
0.61 \\
0.58 \\
0.95 \\
. .54 \\
0.43 \\
\end{array}$ \\
\hline 公 & $\begin{array}{l}\text { Thymidylic acid } \\
\text { Cytidylic acid } \\
\text { Adenine } \\
\text { Guanine } \\
\end{array}$ & $\begin{array}{l}0 \\
0 \\
0 \\
0 \\
\end{array}$ & $\begin{array}{l}2.75 \\
2.04 \\
2.28 \\
1.95 \\
\end{array}$ & $\begin{array}{l}4.10 \\
3.04 \\
\overline{1.88} \\
\end{array}$ & $\begin{array}{l}2.63 \\
4.76 \\
3.79 \\
3.28 \\
\end{array}$ & & $\begin{array}{l}3.33 \\
2.72 \\
3.21 \\
2.45 \\
\end{array}$ & $\begin{array}{l}2.51 \\
2.48 \\
2.03 \\
2.23 \\
\end{array}$ & $\begin{array}{l}1.70 \\
2.28 \\
\overline{1.27} \\
\end{array}$ & $\begin{array}{l}0.88 \\
1.17 \\
0.88 \\
1.16 \\
\end{array}$ \\
\hline 藏 & $\begin{array}{l}\text { Adenine-ribose } \\
\text { Guanine-ribose } \\
\end{array}$ & $\begin{array}{l}1.76 \\
1.74 \\
\end{array}$ & $\begin{array}{l}7.15 \\
5.44 \\
\end{array}$ & $\begin{array}{l}4.00 \\
3.96 \\
\end{array}$ & $\begin{array}{l}2.79 \\
4.06 \\
\end{array}$ & & $\begin{array}{l}1.31 \\
1.29 \\
\end{array}$ & $\begin{array}{l}0.83 \\
1.22 \\
\end{array}$ & $\begin{array}{l}0.54 \\
0.62 \\
\end{array}$ & $\begin{array}{l}0.36 \\
0.63 \\
\end{array}$ \\
\hline 苔 & $\begin{array}{l}\text { Desoxyribose from } \\
\text { purine nucleosides }\end{array}$ & 0.23 & 1.42 & - & 0.59 & & 0.23 & 0.17 & 0.16 & 0.11 \\
\hline \multirow[t]{2}{*}{$\begin{array}{l}.9 \\
\Phi \\
0 \\
0\end{array}$} & $\begin{array}{l}\text { Glutamic acid } \\
\text { Glycine } \\
\text { Methionine } \\
\text { Serine } \\
\text { Leucine }+ \text { isoleucine } \\
\text { Valine } \\
\text { Alanine } \\
\text { Threonine } \\
\text { Aspartic acid } \\
\text { Proline } \\
\text { Tyrosine } \\
\end{array}$ & $\begin{array}{l}1.55 \\
0.05 \\
0.27 \\
1.78 \\
0.93 \\
1.26 \\
3.90 \\
1.17 \\
0.05 \\
0.02 \\
1.31 \\
\end{array}$ & $\begin{array}{r}4.88 \\
0.35 \\
1.01 \\
4.75 \\
3.55 \\
5.29 \\
11.17 \\
3.82 \\
0.95 \\
3.32 \\
3.17 \\
\end{array}$ & $\begin{array}{r}7.79 \\
0.64 \\
2.05 \\
4.85 \\
7.99 \\
10.57 \\
12.93 \\
2.15 \\
2.65 \\
5.23 \\
5.23 \\
\end{array}$ & $\begin{array}{r}11.04 \\
0.26 \\
2.69 \\
5.91 \\
12.50 \\
13.45 \\
14.19 \\
6.74 \\
5.58 \\
9.80 \\
5.88\end{array}$ & $\begin{array}{l}2.05 \\
0.60 \\
-\overline{2} \\
2.58 \\
2.86 \\
2.62 \\
3.35 \\
3.43 \\
- \\
- \\
\end{array}$ & $\begin{array}{l}3.03 \\
0.64 \\
3.01 \\
1.64 \\
2.66 \\
2.75 \\
2.07 \\
3.96 \\
3.65 \\
3.01 \\
2.48 \\
\end{array}$ & $\begin{array}{l}3.17 \\
0.45 \\
2.90 \\
2.03 \\
2.45 \\
1.94 \\
2.46 \\
3.25 \\
3.24 \\
2.82 \\
2.35 \\
\end{array}$ & $\begin{array}{l}2.26 \\
0.54 \\
1.89 \\
1.01 \\
2.12 \\
1.75 \\
1.81 \\
2.45 \\
3.02 \\
2.23 \\
1.73 \\
\end{array}$ & $\begin{array}{l}1.75 \\
0.43 \\
0.99 \\
0.93 \\
1.51 \\
1.32 \\
2.19 \\
2.78 \\
1.57 \\
1.45 \\
1.94\end{array}$ \\
\hline & $\begin{array}{l}\text { Glucose from gly- } \\
\text { cogen }\end{array}$ & 5.9 & 8.2 & 8.7 & 10.3 & 1.55 & 0.87 & 0.59 & 0.59 & 0.44 \\
\hline
\end{tabular}

Table 5. Amount of ${ }^{13} \mathrm{C}$ in the cells per litre of culture.

\begin{tabular}{|c|c|c|c|}
\hline $\begin{array}{c}\text { Cultivation time } \\
\text { in min }\end{array}$ & $\begin{array}{c}\text { I } \\
\text { Dry weight of } \\
\text { cells per litre, mg }\end{array}$ & $\begin{array}{c}\text { II } \\
{ }^{13} \mathrm{C} \text { Atom per cent } \\
\text { excess in total cell }\end{array}$ & $\mathrm{I} \times \mathrm{II}$ \\
\hline 0 & 41.2 & 3.15 & 130 \\
5 & 45.7 & 2.75 & 123 \\
25 & 57.2 & 2.31 & 134 \\
50 & 100.6 & 1.76 & 121 \\
80 & 1.24 & $\mathrm{M}=126 \pm 5$ \\
\hline
\end{tabular}


to be considered when using the labeling of carbon for calculations. ${ }^{14} \mathrm{C}$ was determined on plates at "infinite" thinness. The lactates used as substrates were racemic. It was still racemic after the harvesting of the cells. In experiments in which the amount of new synthesized glycogen could be determined accurately and in which probably no "old glycogen" was degraded, this new synthesized glycogen had the same specific activity as the medium glucose, when totally labeled glucose was used. This was certainly not the case when $\beta$-labeled lactate was used, as in the present experiments. The specific activity in glycogen was only $30 \%$ of the specific activity of the medium lactate. In recent work ${ }^{10}$ on spores from Penicillium brevicompactum with ${ }^{14} \mathrm{C}$-labeled glucose as carbon source it was shown that RNA in the lag phase incorporated considerable amounts of cellular carbon. It seems also that the methyl carbon in lactate has not been used to the same extent as carbon atoms 1 and 2 .

Table 5, col. 4, demonstrates that the product of ${ }^{13} \mathrm{C}$ in total cells and their dry weight per litre was constant. The variations are irregularly distributed. This indicates that little if any carbon had left the cells during the cultivation time. The assumption is made that all carbon-containing substances in the cells from the stationary phase of preculture were labeled with ${ }^{13} \mathrm{C}$. The same calculation for RNA, protein and glycogen show greater irregularities which could be expected on account of the difficulties of the tracer analyses in the purified substances. Still, the figures show that there cannot be any considerable exchange of the carbon present in RNA at zeco time with other cellular components during the $80 \mathrm{~min}$ incubation (Table 6).

The protein fraction incorporated carbon from other cellular sources during the first $5 \mathrm{~min}$ of incubation which is indicated by the rise in ${ }^{13} \mathrm{C}$ content (Table 7, col. 4) and by the rise in ${ }^{13} \mathrm{C}$-labeling in several amino acids during the same period (Table 4). During the following period from 5 to $80 \mathrm{~min}$ after incubation the product of protein carbon per litre and atom per cent excess ${ }^{13} \mathrm{C}$ remains fairly constant, demonstrating that the original carbon in proteins was not, or only to a small extent exchanged during this period. Glycogen had incorporated carbon from other cellular sources during the first $50 \mathrm{~min}$ (Table 7, col. 7). Protein carbon was higher labeled than glycogen and the amount of this was not more than 1 to $15 \%$ of the protein carbon. The incorporation of carbon from the medium into glycogen starts during the first $5 \mathrm{~min}$ (Table 3, col. 8). It may well be that cell carbon, incorporated into glycogen, is derived from remaining ${ }^{13} \mathrm{C}$-lactate or other low molecular precursors. A small part may have been derived from brokendown protein.

In Table 8 the quotients are given between the increases from zero time at each investigated cultivation time in amounts per litre found by direct analysis (numerator) and the same amounts (denominator) calculated from the labeling. In this calculation the total amount per litre at each investigated cultivation time was multiplied with the labeling at the corresponding time in relation to the labeling in the medium.

The net synthesis of protein in $80 \mathrm{~min}$, determined by nitrogen analysis $(54 \%)$ agrees well with the synthesis as calculated from the labeling with ${ }^{15} \mathrm{~N}(53 \%)$. This shows that the incorporation of ${ }^{15} \mathrm{~N}$ into protein may be

Acta Chem. Scand. 11 (1957) No. 8 
Table 6. Amount of ${ }^{18} \mathrm{C}$ in RNA per litre of culture.

\begin{tabular}{|c|c|c|c|}
\hline $\begin{array}{c}\text { Cultivation time } \\
\text { in min }\end{array}$ & $\begin{array}{c}\text { I } \\
\text { RNA-phosphorus } \\
\text { per litre of culture }\end{array}$ & $\begin{array}{c}\text { II } \\
\text { Atom per cent } \\
\text { excess }{ }^{13} \text { C in RNA }\end{array}$ & I $\times$ II \\
\hline 0 & 0.28 & - & - \\
5 & 0.33 & 2.28 & 0.76 \\
25 & 0.59 & 1.25 & 0.68 \\
50 & 0.79 & 0.84 & 0.67 \\
80 & 1.31 & 0.58 & 0.76 \\
\hline
\end{tabular}

Table 7. Amount of ${ }^{13} \mathrm{C}$ in protein and glycogen in the cells per litre of culture.

\begin{tabular}{|c|c|c|c|c|c|c|}
\hline \multirow[b]{2}{*}{$\begin{array}{l}\text { Cultivation } \\
\text { time in min }\end{array}$} & \multicolumn{3}{|c|}{ Protein } & \multicolumn{3}{|c|}{ Glycogen } \\
\hline & \begin{tabular}{|c}
$\mathrm{I}$ \\
Protein carbon \\
per litre, $\mathrm{mg}^{1}$
\end{tabular} & $\begin{array}{c}\text { II } \\
\text { Atom per cent } \\
\text { excess }{ }^{13} \mathrm{C}\end{array}$ & $I \times I I$ & $\begin{array}{c}\text { I } \\
\text { Glycogen } \\
\text { carbon per } \\
\text { litre, mg }\end{array}$ & $\begin{array}{c}\text { II } \\
\text { Atom per } \\
\text { cent excess } \\
{ }^{13} \mathrm{C}\end{array}$ & $I \times I I$ \\
\hline $\begin{array}{r}0 \\
5 \\
25 \\
50 \\
80\end{array}$ & $\begin{array}{l}17.4 \\
17.6 \\
21.3 \\
25.2 \\
37.7 \\
\end{array}$ & $\begin{array}{l}2.32 \\
2.65 \\
2.13 \\
1.77 \\
1.24\end{array}$ & $\begin{array}{l}40 \\
47 \\
45 \\
45 \\
47\end{array}$ & $\begin{array}{l}0.22 \\
1.21 \\
2.80 \\
3.90 \\
4.16 \\
\end{array}$ & $\begin{array}{l}1.55 \\
0.87 \\
0.59 \\
0.59 \\
0.44\end{array}$ & $\begin{array}{l}0.34 \\
1.05 \\
1.65 \\
2.30 \\
1.83\end{array}$ \\
\hline
\end{tabular}

$14.08 \times$ Nitrogen $=$ Carbon.

Table 8. Ratio between the increase in amount, as measured by direct analysis to the increase, as measured by isotopic labeling.

\begin{tabular}{|c|c|c|c|c|c|c|c|c|}
\hline \multirow[b]{2}{*}{$\begin{array}{l}\text { Cultivation } \\
\text { time in min }\end{array}$} & \multirow{2}{*}{$\begin{array}{c}\begin{array}{c}\text { Total } \\
\text { cell }\end{array} \\
\text { calc. } \\
\text { from } \\
{ }^{15} \mathrm{~N}\end{array}$} & \multicolumn{2}{|c|}{ Protein } & \multicolumn{2}{|c|}{ RNA } & \multicolumn{2}{|c|}{ DNA } & \multirow{2}{*}{$\begin{array}{c}\text { Glycogen } \\
\text { calc. } \\
\text { from } \\
{ }^{4} \mathrm{C}\end{array}$} \\
\hline & & $\begin{array}{l}\text { calc. } \\
\text { from } \\
{ }^{15} \mathrm{~N}\end{array}$ & $\begin{array}{l}\text { calc. } \\
\text { from } \\
{ }^{14} \mathrm{C}\end{array}$ & $\begin{array}{l}\text { calc. } \\
\text { from } \\
{ }^{15} \mathrm{~N}\end{array}$ & $\begin{array}{l}\text { calc. } \\
\text { from } \\
{ }^{14} \mathrm{C}\end{array}$ & $\begin{array}{l}\text { cale. } \\
\text { from } \\
{ }^{15} \mathrm{~N}\end{array}$ & $\begin{array}{l}\text { calc. } \\
\text { from } \\
{ }^{14} \mathrm{C}\end{array}$ & \\
\hline 5 & 0.83 & $(0.50)$ & $(0.43)$ & 2.25 & 2.70 & (8.6) & - & 1.30 \\
\hline 25 & 1.20 & 1.19 & 1.22 & 1.86 & 2.12 & 2.8 & 4.6 & 1.40 \\
\hline 50 & 0.92 & 0.92 & 1.35 & 1.42 & 2.70 & 2.1 & 2.7 & 1.42 \\
\hline 80 & 1.00 & 1.02 & 1.27 & 1.21 & 3.56 & 1.6 & 3.5 & 1.53 \\
\hline
\end{tabular}

taken as a measure of the net synthesis of protein during active growth in bacterial cells at least when the sole source of nitrogen is $\mathrm{NH}_{4} \mathrm{Cl}$.

The quotients (Table 8 ) calculated for protein at $5 \mathrm{~min}$ are probably not significant, since the figure for net synthesis is too near the limits of the analytical error. Otherwise the quotients both for total cells and for proteins show no systematical variation. Thus the protein incorporated its nitrogen 
exclusively or nearly so from the medium. The quotients from the calculation from ${ }^{14} \mathrm{C}$ increase with the cultivation time. As protein incorporates very little if any carbon from the cell carbon between 5 and $80 \mathrm{~min}$, the possibility is not excluded that during this period of carbon incorporation some change in selectivity occurs in the use of the three lactate carbons. The same relative decrease of the incorporation of labeled carbon from the lactates in the medium turns up in the quotients for glycogen, though less marked. The quotients for RNA as calculated from the content of ${ }^{15} \mathrm{~N}$ go in opposite way from 2.30 to 1.21 , showing that RNA in earlier stages incorporates comparatively much nitrogen from the cells, whilst the medium as time passes on is furnishing more and more of the nitrogen. The quotients calculated from ${ }^{14} \mathrm{C}$ are probably too inaccurate for being safely interpreted. It was shown (Table 6) that RNA does not change its total ${ }^{13} \mathrm{C}$-content much. The fact that the quotients (Table 8) are high may signify that carbon atoms 1 and 2 in the medium-lactate are more extensively used than carbon 3. The quotients for DNA are even more erratic than those for RNA but show the same general tendency. The most rapidly formed of the four components investigated, glycogen, was using cell carbon proportionally more than any of the others, and RNA (and DNA) acted in a similar way in respect to nitrogen in early stages of synthesis. Except for a small uptake of cellular carbon during the first $5 \mathrm{~min}$ protein was mainly synthesized from the medium.

The very first part of the lag-phase seems thus to be characterized by a redistribution of the cellular carbon. This redistribution still operates later on in the lag-phase, but to a smaller extent. In the later part of the lagphase the synthesis from medium constituents dominates.

\section{REFERENCES}

1. Cavanna, R., Chain, E. B., Hedén, C. G., Malmgren, B., Eliasson, N. A., Hammarsten, E. and Aqvist, S. Rendiconti Dell Instituto Superiore Di Sanita: 17 (1954) 1284.

2. Palmstierna, H. Studies on a glycogenlike polysaccharide in Escherichia coli B, Diss., Stockholm 1956.

3. Hammarsten, E. Acta Med. Scand. Suppl. 196 (1947) 634.

4. Cohn, W. E. J. Am. Chem. Soc. 72 (1950) 1471.

Cohn, W. E. and Volkin, Nature, 167 (1951) 483; Arch. Biochem. and Biophys. 35 (1952) 465; J. Biol. Chem. 203 (1953) 319.

5. Hurst, R. O., Little, J. A. and Butler, G. L. J. Biol. Chem. 188 (1951) 705.

6. Aquist, S. Acta Chem. Scand. 5 (1951) 1031.

7. Reio, L. To be published.

8. Koenemann, R. H. J. Biol. Chem. 135 (1940) 105.

9. Hammarsten, E. and Palmstierna, H. Acta Chem. Scand. 11 (1957) 1378.

Received June 3, 1957. 